\title{
Avaliação Das Complicações em Pacientes com Cirrose em Nível Ambulatorial
}

\author{
Contiero, P.; Silva, R.R.; Mattos, A.A.; Comerlato, P.H.; Porto, M.; Miozzo, \\ S.A.S.; John, J.A.;
}

Apresentador: Priscila Contiero

\section{Resumo}

Introdução: A cirrose, estágio final das doenças hepáticas crônicas, geralmente evolui com complicações graves. As principais complicações são ascite, peritonite bacteriana espontânea (PBE), encefalopatia hepática $(\mathrm{EH})$, hemorragia digestiva alta (HDA), carcinoma hepatocelular (CHC). O objetivo deste estudo é avaliar a prevalência e a evolução das complicações clínicas em pacientes com diagnóstico de cirrose atendidos em um ambulatório terciário. Métodos: Foi realizado um estudo de coorte, observacional e retrospectivo em 527 pacientes com diagnóstico de cirrose e acompanhamento em ambulatório entre março de 2005 a março de 2010 (revisão de prontuários). Foram incluídos os com seguimento mínimo de um ano. Foram excluídos casos de co-infecção com HIV, transplante de órgãos prévio, diagnóstico de $\mathrm{CHC}$ avançado no primeiro atendimento, ausência de registro e perda de seguimento. Critérios para etiologias: vírus da hepatite $\mathrm{C}(\mathrm{VHC})$ - anti-HCV + PCR vírus da hepatite B (VHB) - HBsAg + PCR Álcool - ingestão $>80 \mathrm{~g} / \mathrm{d}$ por 10 anos (homens) ou 40g (mulheres) Outros diagnóstico histológico ou por exclusão. O projeto foi aprovado pelo CEP institucional. Os dados foram analisados com o programa SPSS 18.0. Resultados: No início do seguimento, as principais complicações encontradas foram ascite (32\%), HDA (16\%), EH (11\%), PBE (6\%) e CHC (5\%). Ao final do acompanhamento, ascite permaneceu como a complicação mais comum (34\%), seguida pelo CHC (17\%), EH (17\%), PBE (13\%) e HDA (7\%). Houve um aumento significativo na frequência de $\mathrm{CHC}$, aumentando de 26 para 87 casos $(p=0,005)$. Ao ser considerada a etiologia da cirrose para análise das complicações, observou-se que ascite foi a mais frequente para todas as etiologias, tanto no início, quanto no final do seguimento. Os pacientes com etiologia por VHC, associado ou não ao álcool, evoluíram com maior prevalência de complicações. Conclusão: Ascite foi a complicação mais prevalente, independentemente da etiologia da cirrose. A presença e a evolução das complicações foram diferentes quando se considerou a etiologia, sendo que o grupo VHC evoluiu com mais complicações. O surgimento de 61 novos casos de $\mathrm{CHC}$ evidencia a importância de se estabelecer um programa de rastreamento nos pacientes com cirrose. A prevalência e a gravidade das complicações ressaltam a importância do acompanhamento regular desses pacientes em um serviço de saúde.

\section{Referência:}

Contiero, P.; Silva, R.R.; Mattos, A.A.; Comerlato, P.H.; Porto, M.; Miozzo, S.A.S.; John, J.A.;. Avaliação Das Complicações em Pacientes com Cirrose em Nível Ambulatorial. In: II Congresso Brasileiro de Medicina Hospitalar - II CBMH [= Blucher Medical Proceedings, vol.1, num.5] São Paulo: Editora Blucher, 2014. p.11

DOI 10.5151/medpro-II-cbmh-002 